\title{
SĄSIEDZKI KAPITAŁ SPOŁECZNY A UŻYWANIE SUBSTANCJI PSYCHOAKTYWNYCH PRZEZ MŁODZIEŻ
}

\author{
NEIGHBOURHOOD SOCIAL CAPITAL \\ AND USE OF PSYCHOACTIVE SUBSTANCES BY ADOLESCENTS
}

\begin{abstract}
A b s t r a c t. The aim of the article is to describe the relationship between neighboring social capital and problem behaviors of young people, which one of the manifestations is the use of psychoactive substances. Theoretical part of article is a review of the literature on social capital and its understanding by the authors presenting different scientific approaches. Then it describes the importance of neighborly relations in the modern world. Article also includes the epidemiological analysis of psychoactive substances consumption by young people. Theoretical considerations are summarized by presentation of the Jessor's Problem Behavior Theory, which contains the neighborly relations as a protecting factor against the occurrence of risky behavior among young people. The empirical part of the article presents the results of research conducted on a group of young people from Lublin province. This part shows the relationship between owned neighboring relations and the use of legal and illegal psychoactive substances.
\end{abstract}

Key words: social capital; neighborhood; psychoactive substances use; Problem Behavior Theory. \footnotetext{
Mgr AgNiesZKa PALACZ-Chrisidis - Instytut Psychologii KUL; palaczagnieszka@ onet.eu

Dr Michą WiecheteK - Instytut Psychologii KUL; wiechetek@kul.lublin.pl

Dr hab. IwONA NiEWIADOMSKa, prof. KUL - Instytut Psychologii KUL. lublin.pl

Dr hab. StAnisŁaW FEL, prof. KUL - Instytut Socjologii KUL; stanislaw.fel@ kul.

Dr JoAnna ChWASzCZ - Instytut Psychologii KUL; chwaszcz@kul.pl

Dr RAFAE P. BARTCZUK - Instytut Psychologii KUL; bartczuk@kul.lublin.pl
} gmail.com

DrWERONIKA AUGUSTYNOwICZ - Instytut Psychologii KUL; weronika.augustynowicz@ 


\section{SĄSIEDZKI KAPITAŁ SPOŁECZNY}

Współcześnie jakość relacji sąsiedzkich wpisywana jest w szerszą kategorię określaną mianem kapitału społecznego. Jak wskazuje R.D. Putnam ${ }^{1}$, politolog i autor jednej z najczęściej przytaczanych definicji kapitału społecznego, termin ten wynajdywano co najmniej sześciokrotnie w ciągu ubiegłego stulecia, ale za każdym razem zwracano uwagę na fakt wpływu więzi społecznych na efektywność życia ludzkiego. Po raz pierwszy określenia „kapitał społeczny" użyła L.J. Hanifan. Zaproponowana przez autorkę definicja wskazuje m.in. na korzyści płynące z nawiązywania relacji sąsiedzkich: „Jednostka jest społecznie bezradna, jeśli jest pozostawiona sama sobie. [...] Jeśli wchodzi ona w kontakt ze swoimi sąsiadami, nastąpi akumulacja kapitału społecznego, który może natychmiast zaspokoić jej potrzeby społeczne i który może nieść potencjał społeczny wystarczający do istotnego poprawienia warunków życiowych w całej wspólnocie"2. Odnosząc powyższą definicję do problemu poruszanego w tym artykule, można wysunąć przepuszczenie, iż generowany przez więzi sąsiedzkie kapitał społeczny powinien oddziaływać jako czynnik ochraniający przed różnymi formami patologii, występującymi w danej wspólnocie. Teza ta znajduje swoje odzwierciedlenie również $\mathrm{w}$ poglądach J. Jacobs ${ }^{3}$, która uważa, że gęste sieci stosunków społecznych, szczególnie zauważalne w starszych dzielnicach miejskich, sprzyjają bezpieczeństwu publicznemu.

Pojęcie kapitału społecznego było podejmowane na przestrzeni XX wieku w odniesieniu do bardzo różnych dziedzin naukowych przez takich autorów, jak G. Loury, P. Bourdieu, E. Schlichta, F. Fukuyama. Jednak dopiero za sprawą J.S. Colemana i R.D. Putnama stało się ważnym zjawiskiem, opisywanym na gruncie nauk społecznych ${ }^{4}$. J. Coleman ${ }^{5}$ definiuje kapitał społeczny

${ }^{1}$ R.D. PUTNAM, Samotna gra w kręgle. Upadek i odrodzenie wspólnot lokalnych w Stanach Zjednoczonych, Warszawa: Wydawnictwa Akademickie i Profesjonalne 2008, s. 33.

${ }^{2}$ L.J. Hanifan, The Rural School Community Center, „Annals of the American Academy of Political and Social Science" 67(1916), s. 130-138.

3 J. JACOBS, The Death and Life of Great American Cities, New York 1961, cyt. za: K. SiERocińSKA, Kapitat społeczny. Definiowanie, pomiar $i$ typy, „Studia Ekonomiczne” 1(LXVIII)/2011, s. 69-86.

${ }^{4}$ Zob. B. FeDYSZAK-RADZIEJOWSKA, Kapitat spoteczny wsi $-w$ poszukiwaniu utraconego zaufania, w: K. SzAFRANIEC (red.), Kapitat ludzki i zasoby społeczne wsi. Ludzie - spoteczność lokalna - edukacja, Warszawa: Instytut Rozwoju Wsi i Rolnictwa Polskiej Akademii Nauk 2006, s. 71-120; R.D. PUTnAM, Samotna gra w kregle, s. 33; G. GUDMUNDSSON, P. MiKIEWICZ, Koncepcja kapitału społecznego $i$ jej możliwe użycie $w$ badaniach porównawczych zmierzajacych do wsparcia reform edukacyjnych, w: P. MIKIEWICZ (red.), Kapitat społeczny i edukacja. Badanie porównawcze pomiędzy Polska i Islandia. Raport podsumowujacy, Wrocław: Dolnośląska Szkoła 
poprzez jego funkcję - jako wiele różnych jakości, które mają dwie wspólne cechy: stanowią aspekt kultury społecznej i ułatwiają działania jednostek znajdujących się w tej strukturze. Jest to przede wszystkim atrybut małych grup, w których nawiązywane są silne relacje. Kapitał społeczny umożliwia osiąganie celów, które nie byłyby możliwe do zrealizowania, gdyby go brakowało. W kontekście problemu podjętego w tej publikacji można przepuszczać, iż wspólnoty sąsiedzkie charakteryzujące się silną i bliską relacją swoich członków w lepszy sposób będą ograniczały występowanie patologii społecznych czy zwalczały przejawy pojawiających się zachowań ryzykownych ${ }^{6}$.

Putnam $^{7}$ z kolei akcentuje pozytywne skutki kapitału społecznego, takie jak: wzajemne wsparcie, zaufanie, współpraca, efektywność działań. Autor zauważa, że w celu wzmacniania kapitału społecznego należy działać m.in. w taki sposób, aby ludzie więcej czasu poświęcali na podtrzymanie więzi sąsiedzkich. W efekcie umożliwi to budowanie specyficznego rodzaju kapitału zwanego wiążącym (bonding social capital), który w odróżnieniu od kapitału pomostowego (bridging social capital) - formy zaufania i współpracy osób, które osobiście się nie znają i nie są związane bezpośrednim kontaktem - jest zakorzeniony w strukturach niższego rzędu, takich jak rodzina czy sąsiedztwo $^{8}$. Wzmacnianie kapitału społecznego opiera się więc m.in. na procesie tworzenia więzi społecznych i powiązań międzyludzkich, a co za tym idzie - wzmacnianiu sąsiedzkich relacjii ${ }^{9}$. To właśnie w zaniku sąsiedzkich więzi,

Wyższa 2011, s. 12-31; K. SIEROCIŃSKA, Kapitat społeczny, s. 69-86; K. ZAJDA, Czym jest kapitat społeczny mieszkańców polskiej wsi, jak go mierzyć i czy warto inwestować w jego wzmocnienie?, „Acta Universitatis Lodziensis. Folia Sociologica” 37(2011), s. 171-185; M. BEDNAREK-SzCZEPAŃSKA, Wiejski kapitat spoteczny we wspótczesnej Polsce. Przeglad badań i uwagi metodyczne, „Acta Universitatis Lodziensis. Folia Geographica Socio-Economica” 13(2013), s. 19-40.

5 J. Coleman, Foundations of Social Theory, Cambridge: Belknap Press 1990, s. 300.

${ }^{6}$ I. NiEWIADOMSKA, Osobowościowe uwarunkowania skuteczności kary pozbawienia wolności, Lublin: Wydawnictwo Katolickiego Uniwersytetu Lubelskiego 2007, s. 269-273.

${ }^{7}$ R.D. PUTNAM, Samotna gra w kręgle.

${ }^{8}$ Zob. M. LEWICKA, Ways to make people active: The role of place attachment, cultural capital, and neighbourhood ties, ,Journal of Environmental Psychology” 25(2005), s. 381-395; B. FEDYSZAK-RADZIEJOWSKA, Kapitat spoteczny wsi $-w$ poszukiwaniu utraconego zaufania, s. 71-120; R.D. PUTNAM, Samotna gra w kregle; T. ZARYCKI, Dwa wymiary kapitału spotecznego w kontekście polskim, „Pomorski Przegląd Gospodarczy” 2 (37)/2008, s. 49-52; I. NIEWIADOMSKA, Funkcje zasobów społecznych $w$ działalności profilaktycznej, w: I. NIEWIADOMSKA, M. KALINOWSKI (red.), Wezwani do działania. Zasoby społeczne w profilaktyce zachowań destrukcyjnych, Lublin: Wydawnictwo Katolickiego Uniwersytetu Lubelskiego 2010, s. 47-66.

${ }^{9}$ Por. S. TORUŃCZYK-RUIZ, Znaczenie sasiedztwa i koncentracji przestrzennej, „Biuletyn Migracyjny" 44(2013), s. 1-2. 
jako podstawy lokalnych społeczności, często upatruje się kryzysu miast, który przejawia się chociażby w upowszechnieniu się zjawisk patologicznych. Natomiast w odnowie więzi sąsiedzkich próbuje się znaleźć rozwiązanie zaistniałych problemów ${ }^{10}$.

Próba zdefiniowania sąsiedztwa nie jest prosta, gdyż jest ono zjawiskiem zróżnicowanym strukturalnie, organizacyjnie i kulturowo. Jedne definicje kładą nacisk na aspekt przestrzennej, fizycznej bliskości, inne bardziej akcentują sieci społecznych powiązań. Typowa idea sąsiedztwa to „najbliższe otoczenie" (home area), gdzie jakość środowiska oraz przestrzeganie i oczekiwania współmieszkańców stymulują przywiązanie i poczucie przynależności, utrzymywanie kontaktów z innymi i okazywanie wspólnych poglądów ${ }^{11}$. Jednak tak rozumiane sąsiedztwo komplikuje fakt postępującej urbanizacji, globalizacji oraz dużej migracji ludzi we współczesnym świecie, co już w latach pięćdziesiątych i siedemdziesiątych XX wieku opisywał R. Sennet ${ }^{12}$. Obecnie w literaturze przedmiotu podkreśla się, że zawężanie sąsiedztwa jedynie do bliskości terytorialnej jest błędne. Należy je bardziej traktować jako zbiór zachodzących na siebie sieci społecznych, które mogą być realizowane chociażby w przestrzeni wirtualnej ${ }^{13}$. Współczesne badania podkreślają i analizują nie tyle zjawiska kryzysu i zaniku więzi sąsiedzkich, ile raczej zmiany zachodzące $\mathrm{w}$ treści sąsiedztwa ${ }^{14}$. Znajduje to swoje odzwierciedle-

\footnotetext{
${ }^{10}$ Zob. I. NiEWIADOMSKA, Zakorzeniania społeczne więźniów, Lublin: Wydawnictwo Katolickiego Uniwersytetu Lubelskiego 2011, s. 175-197; M. BŁASZCZYK, O więzi sqsiedzkiej w środowisku wielkomiejskim - na przykładzie Wroctawia, w: I. BOROwIK, K. SzTALTA (red.), Wspótczesna socjologia miasta. Wielość ogladów i kierunków badawczych dyscypliny, Wrocław: Wydawnictwo Uniwersytetu Wrocławskiego 2007, s. 155-169.

${ }^{11}$ J. BRUHN, Efekt grupy. Spójność społeczna i jej konsekwencje dla zdrowia, Warszawa: Wydawnictwo SWPS Academica 2011, s. 133.

12 R. SENNET, The fall of public man, Cambridge 1977, cyt. za: W. ŁukowsKI, M. GRYGORCZyK, P. HENZLER, A. IWANIAK, K. SeKUTOwicz, Sasiedztwa i mikroorganizacje w polskiej przestrzeni społecznej - próba diagnozy i rekomendacje, Warszawa: Stowarzyszenie CAL Instytut Radliński 2009, s. 16.

13 Zob. K. KRZYSZTOFEK, Wirtualna reterytorializacja:czy istnieje lokalność w cyberprzestrzeni?, w: J. KURCZEWSKA (red.), Oblicza lokalności. Ku nowym formom życia lokalnego, Warszawa: Wydawnictwo IFiS PAN 2008, s. 391-414; W. ŁUKOWSKI, M. GRYGORCZYK, P. HENZLER, A. IWANIAK, K. SEKUTOWICZ, Sasiedztwa i mikroorganizacje w polskiej przestrzeni spotecznej; J. BRUHN, Efekt grupy; A. BUJWICKA, Typy wielkomiejskiego sasiedztwa wyobrażone a praktykowane stosunki sqsiedzkie mieszkańców Lodzi, „Acta Universitatis Lodziensis. Folia Sociologica" 36(2011), s. 101-119; M. SZCZEPAŃSKA, Osiedla grodzone: świadomościowe aspekty podziałów spoteczno-przestrzennych i wieź sqsiedzka, www.socialspacejournal.eu [data pobrania: 23.05.2015].

${ }^{14}$ Zob. E. KALTENBERG-KwIATKOWSKA, Sasiedztwo we wspótczesnym mieście - stereotypy
} 
nie w tworzeniu różnych typologii sąsiedztwa, co jeszcze bardziej podkreśla wielowymiarowość opisywanego pojęcia.

W polskiej literaturze najczęściej można spotkać odwołania do typologii zaproponowanych przez J. Turowskiego i P. Kryczkę. Pierwszy z autorów wyróżnia trzy rodzaje układów sąsiedzkich, takich jak: sąsiedztwo znajomościowo-świadczeniowe - najbliższe tradycyjnemu rozumieniu stosunków sąsiedzkich; sąsiedztwo znajomościowo-ceremonialne, ograniczające się jedynie do wymiany grzeczności, bez nawiązywania głębszych relacji, oraz sąsiedztwo poinformowane, które polega na zbieraniu informacji o sąsiadach ${ }^{15}$. Z kolei P. Kryczka ${ }^{16}$ wyróżnia sąsiedztwo ograniczające - sprowadzające się do unikania zachowań, które mogą być traktowane przez innych jako nieodpowiednie; konwencjonalne - polegające na wymianie grzeczności, jest to rodzaj sąsiedztwa pełniącego rolę socjalizująca; poinformowane - zgodne z rozumieniem J. Turowskiego; świadczeniowe - oparte na zasadach wzajemności wyświadczania sobie wzajemnych przysług; solidarnościowe - oparte na relacji dobra wspólnego, związane z poczuciem nadrzędności i jedności interesów, wynikających z bliskości zamieszkania; oraz towarzysko-przyjacielskie - cechujące się bardziej bliskimi kontaktami o charakterze koleżeńskim ${ }^{17}$. Jak wynika $\mathrm{z}$ badań, najczęściej preferowanymi typami sąsiedztwa w Polsce są sąsiedztwo konwencjonalne, świadczeniowe oraz towarzyskie ${ }^{18}$.

W literaturze przedmiotu możemy znaleźć próby łączenia sąsiedztwa i ogólnie pojętej jakości życia mieszkańców. Sąsiedztwo, szczególnie to z wysokim kapitałem społecznym, stanowi dla jednostki system wsparcia psychicznego i ekonomicznego. Jest ono także podstawowym źródłem nieformalnej kontroli społecznej

i rzeczywistość, w: W. MisZTAL, J. STYK (red.), Stare i nowe struktury społeczne w Polsce, t. III: Czynniki miastotwórcze $w$ okresach wielkich zmian społecznych, Lublin: Wydawnictwo Uniwersytetu Marii Curie-Skłodowskiej 2002, s. 253-280; M. STRZESZEWSKI, Kontakty sqsiedzkie w miejscu zamieszkania. Komunikat z badań, Warszawa: Centrum Badania Opinii Społecznej 2008.

15 J. TUROwSKI, Ksztattowanie się zbiorowości osiedlowej $w$ wielkim mieście, „Studia Socjologiczne” 1(1976), s. 20-32. Por. M. BŁASZCZYK, O więzi sqsiedzkiej w środowisku wielkomiejskim - na przykładzie Wroctawia.

${ }^{16}$ P. KRYCZKA, Społeczność osiedla mieszkaniowego w wielkim mieście. Ideologie i rzeczywistość, Warszawa: PWN 1981.

${ }^{17}$ Por. E. KALtenberg-KwiatKowsKa, Sasiedztwo we wspótczesnym mieście - stereotypy i rzeczywistość; M. BŁASZCZYK, O więzi sasiedzkiej w środowisku wielkomiejskim; M. STRZESZEWSKI, Kontakty sasiedzkie w miejscu zamieszkania; A. BUJWICKA, Typy wielkomiejskiego sasiedztwa; M. SZCZEPAŃSKA, Osiedla grodzone.

${ }^{18}$ M. STRZESZEWSKI, Kontakty sqsiedzkie w miejscu zamieszkania; por. M. BŁASZCZYK, $O$ więzi sasiedzkiej w środowisku wielkomiejskim. 
oraz przekaźnikiem ważnych wartości i tradycji społecznych ${ }^{19}$. Aspekt kontroli społecznej w spójnych społecznie sąsiedztwach podkreśla również R.J. Samp$\operatorname{son}^{20}$. Zbiorowa skuteczność rozumiana przez tego autora jako społeczna spójność sąsiadów powiązana $\mathrm{z}$ ich skłonnością do interwencji w imię powszechnego dobra, okazała się dobrym predyktorem poziomu przestępczości i przemocy w sąsiedztwie ${ }^{21}$. M. Szczepańska ${ }^{22}$, analizując w prowadzonych przez siebie badaniach treści wpisów na forach wspólnot mieszkaniowych, również wyodrębniła dyskusje, których wspólnym tematem była kontrola sąsiedzka wobec osób nieprzestrzegających norm, jakie powinni respektować członkowie danej wspólnoty mieszkaniowej. A. Pawełczyńska, analizując sposób formowania się młodzieżowych grup przestępczych, wśród pięciu sposobów zawierania znajomości przez nieletnich wymienia sąsiedztwo ${ }^{23}$. J. Bruhn ${ }^{24}$ podkreśla, że kontekst sąsiedztwa jest zmienną pośrednicząca dla zdrowia fizycznego i psychicznego, w tym bycia ofiarą przemocy oraz występowania chorób. Z kolei Y. Xue wraz ze współpracownikami ${ }^{25}$ odnotowali, iż w sąsiedztwach cechujących się biedą występuje więcej problemów ze zdrowiem psychicznym wśród nastolatków. T.E. i S.C. Duncanowie ${ }^{26}$, analizując związek sąsiedztwa $\mathrm{z}$ problemami używania substancji psychoaktywnych przez młodzież, wykazali, że sąsiedztwa mniej spójne oraz biedniejsze są dotknięte większą ilością problemów związanych z używa-

${ }^{19}$ A. BARCZYKOWSKA, Kapitat spoteczny a zjawiska patologii spotecznej $w$ wielkim mieście, Kraków: Oficyna Wydawnicza „Impuls” 2011, s. 10.

${ }^{20}$ R.J. SAMPSON, The neighborhood context of well-beig, „Perspectives in Biology and Medicine" 46(2003), s. 553-564.

${ }^{21}$ Por. Л.А. ЖурАвЛЕвА, Учет в Подготовке педагоГов профессионального обучения виктимизации молодежи в городском пространстве, w: С.3. ГонЧАРОВА (ред.), Креативность гуманитарного образования: духовно-ценностные и интеллектуальные аспекты, Екатеринбург: РГППУ 2014, s. 180-199.

22 M. SZCZEPAŃSKA, Osiedla grodzone.

23 A. PAWEECZYŃSKA, Patologie społeczne $w$ rodzinie a nieprzystosowanie spoteczne ucznia, „Nowa Szkoła” 10(1999), cyt. za: P. MigAŁA, Wybrane elementy patologii spotecznej w aspekcie ich uwarunkowań, Józefów: Wydawnictwo Wyższej Szkoły Gospodarki Euroregionalnej 2011.

24 J. BRUHN, Efekt grupy.

${ }^{25}$ Y. Xue, T. Leventhal, J. Brooks-Gunn, F.J. EARLs, Neighborhood residence and mental health problems of 5- to 11-year olds, „Archieves of General psychiatry” 62 (5)/2005, s. $554-563$.

26 S.C. DunCAN, T.E. DunCAn, A.L. STRYCher, A multilevel analysis of neighborhood context and youth alcohol and drug problems, ,Prevention Science” 3(2)/2002, s. 125-133; T.E. Duncan, S.C. Duncan, H. OKut, A.L. Strycher, H. Hix-SMall, A multilevel contextual model of neighborhood collective efficacy, „American Journal of Community Psychology” 32 $(3 / 4) / 2003$, s. $245-252$. 
niem alkoholu i narkotyków. Było to również istotnie statystycznie skorelowane z liczbą aresztowań osób młodych. Rezultaty te są zgodne z badaniami A.B. Пoгосов і współpracowników ${ }^{27}$, którzy wykazali, iż ponad połowa badanej przez nich młodzieży jako powód używania środków psychoaktywnych wskazała wpływ sąsiadów.

\section{UŻYWANIE SUBSTANCJI PSYCHOAKTYWNYCH PRZEZ MŁODZIEŻ}

W literaturze przedmiotu możemy znaleźć wiele dowodów na to, że bliskie relacje z sąsiadami zwiększają bezpieczeństwo w okolicy, natomiast bezosobowe, powierzchowne i nietrwałe więzi międzyludzkie często współwystępuja z różnorodnymi zachowaniami ryzykownymi, co ma szczególne znaczenie w przypadku młodzieży.

Zachowanie ryzykowne w okresie adolescencji stanowi każda czynność, która odbiega od społecznie akceptowanych norm, wywołuje społeczną naganę bądź upomnienie, oraz naraża jednostkę na reakcję o charakterze kontroli ze strony społeczeństwa $^{28}$. Zachowanie problemowe natomiast stwierdza się u osób, które cechują się szczególnym zespołem postaw, wartości oraz percepcji ${ }^{29}$. Adolescenci z zachowaniami problemowymi są niekonwencjonalni w zakresie wyznawanych wartości, przypisują mniejszą wartość osiągnięciom szkolnym a większą niezależności. Są tolerancyjni wobec dewiacji, a przy podejmowaniu decyzji opierają się silniej na wpływach rówieśników niż rodziców ${ }^{30}$.

\footnotetext{
${ }^{27}$ А.В. ПоГОСов, Н.С. СТЕПАшОВ, Т.А. ФИЛАТОВА, О.М. БУЛАТНИКОВА, Основные направления профилактики зависимости от психоактивных средств в подростковой среде, w: А.И. ЛАЗАРЕВ, В.А. ЛАЗАРЕНКО, О.О. КУРИЛОВА (ред.), Үниверситетская наука: теория, практика, инновации, Курск: ГОУ ВПО КГМУ Росздрава 2008, s. 298303.

${ }^{28}$ R. JESSOR, Risk Behavior in Adolescence: A Psychological Framework for Understanding and Action, ,Journal of Adolescent Health” 12(1991), s. 597-605.

${ }^{29}$ B. LAVERY, A.W. SIEGEL, Adolescent risk - taking: An analysis of problem behaviors in problem children, „Journal of Experimental Child Psychology” 55(1993), s. 277-294.

${ }^{30}$ R. JESSOR, Risk Behavior in Adolescence, s. 597-605; I. NIEWIADOMSKA, Kariera przestepcza a subkultury młodzieżowe, w: E. RUSINIAK (red.), Ograniczenie przestępczości i aspotecznych zachowań „,Razem bezpieczniej”. Działania resortu spraw wewnętrznych i administracji oraz innych podmiotów wspótpracujacych na rzecz porzadku publicznego oraz przeciwdziatania patologiom społecznym, Warszawa: Ministerstwo Spraw Wewnętrznych i Administracji, Komenda Główna Policji 2007, s. 118-129.
} 
Należy podkreślić, że okres rozwojowy adolescencji w szczególny sposób sprzyja ryzyku używania i/lub nadużywania środków psychoaktywnych. Wynika to $\mathrm{z}$ faktu, że z jednej strony dojrzewanie jest zjawiskiem psychobiologicznym, zaś z drugiej - społecznym ${ }^{31}$. Według Amerykańskiego Stowarzyszenia Medycznego, adolescenci często identyfikują się ze specyficznymi stylami życia, które stanowią poważne zagrożenia dla ich zdrowia. Najczęstszym zachowaniem ryzykownym w okresie adolescencji jest spożywanie alkoholu, a ponadto: nikotynizm, narkomania, lekomania, stosowanie dopalaczy, zachowania agresywne, brak dyscypliny szkolnej oraz ucieczki z domu ${ }^{32}$.

Używanie alkoholu przez dzieci i młodzież nie jest zjawiskiem kulturowo nowym, ale współcześnie zyskuje inny wymiar ilościowy i jakościowy - m.in. poprzez: obniżanie się wieku inicjacji alkoholowej, zwiększoną konsumpcję, wzrost spożycia napojów wysokoprocentowych (wódek), mieszanie alkoholu z innymi substancjami psychoaktywnymi, zwiększenie spożycia w populacji dziewcząt ${ }^{33}$. Dane Światowej Organizacji Zdrowia na temat inicjacji alkoholowej młodzieży pokazuja, że zarówno chłopcy, jak i dziewczęta w wielu krajach europejskich pierwszy raz sięgnęli po alkohol między 13 a 14 rokiem życia ${ }^{34}$. Niepokojące dane podaje również najnowszy raport $\mathrm{z}$ badań ESPAD (European School Survey on Alcohol and Other Drugs) - średnio 70\% europejskiej młodzieży w wieku 15-16 lat spożywało alkohol ${ }^{35}$. Jeśli chodzi o polskich nastolatków, to po alkohol sięga aż $78 \%$ z nich, natomiast co trzeci badany przyznaje się do upicia. Według raportu ESPAD z 2011 r., około 87\% uczniów trzeciej klasy gimnazjum spożywało alkohol, natomiast odsetek ten u młodzieży w drugiej klasie szkół średnich i zawodowych wynosi już $95 \%{ }^{36}$. Około $1,5 \mathrm{mln}$ osób poniżej osiemnastego roku życia $(4,0 \%$

${ }^{31}$ I. NiEWIAdOMSKA, Innowacyjny Program Integralny P III. AUCTORIZO LIBERTAS Model wczesnej interwencji socjalnej. Program profilaktyczny (interwencyjny) zapobiegajacy zachowaniom autodestrukcyjnym u młodzieży o podwyższonym ryzyku uzależnienia od substancji psychoaktywnych (P III. zawierajacy K1-K10), Lublin 2013, s. 9.

$32 \mathrm{P}$. KeLLEY, The dangerousness of youth-at-risk: The possibillities of surveillance and intervention in uncertain times, ,Journal of Adolescence” 23(2000), s. 463-476.

33 I. NiEWIAdOMSKA, Innowacyjny Program Integralny P III, s. 9-10.

${ }^{34}$ P. Anderson, B. Baumberg, A Public Health Perspective. Alcohol in Europe, London: Institute of Alcohol Studies for the European Commission 2006, s. 70.

${ }^{35}$ B. Hibell, U. Guttormsson, S. Ahlström, O. Balakireva, T. BJarnason, A. KoKKeVI, L. Kraus, The 2011 ESPAD Report. Substance Use Among Students in 36 European Countries, Stockholm 2012, s. 66-73.

36 J. SiEROSŁAWSKI, Używanie alkoholu i narkotyków przez młodzież szkolna. Raport z ogólnopolskich badań ankietowych zrealizowanych $w 2011$ r., Warszawa 2011, s. 19-37. 
populacji) wychowuje się $\mathrm{w}$ rodzinach, w których jeden $\mathrm{z}$ członków jest uzależniony od alkoholu ${ }^{37}$.

Dostępne dane wskazują również na spożywanie przez młodzież innych substancji psychoaktywnych. Ponad połowa uczniów z krajów uczestniczących w badaniu ESPAD z 2011 r. paliła papierosy przynajmniej raz, a około jedna trzecia spośród wszystkich ankietowanych stwierdziła, że paliła papierosy wciągu ostatniego miesiąca przed badaniem. Jedynie $2 \%$ spośród badanych uczniów w ciągu ostatniego miesiąca paliła jedną paczkę papierosów dziennie. Użycie nielegalnych narkotyków przynajmniej raz w życiu przez młodzież w Europie dotyczy średnio 21\% chłopców oraz 15\% dziewcząt. Podobnie jak wśród osób dorosłych, marihuana jest najczęściej używanym narkotykiem w samym 2010 r. użycie konopi indyjskich zgłosiło 13\% spośród ankietowanych uczniów. Krajami o najwyższych odsetkach użycia marihuany, przynajmniej raz w życiu, przez młodzież w Europie są Czechy (42\%), a także Francja i Monako (35-39\%). Drugim po konopiach narkotykiem najczęściej używanym przez młodzież europejską jest ecstasy oraz amfetamina. Ponad 3\% badanych uczniów przynajmniej raz w życiu użyło ecstasy i amfetaminy. Natomiast znacznie rzadziej młodzież sięga po kokainę, crack, LSD oraz inne halucynogeny (2\%), a heroinę i GHB używał tylko $1 \%$ badanych uczniów ${ }^{38}$.

Według najnowszego raportu Europejskiego Centrum Monitorowania Narkotyków i Narkomanii (EMCDDA) z 2015 r., ponad 25\% osób w wieku 1534 lata, zamieszkujących tereny państw Unii Europejskiej, przynajmniej jednokrotnie próbowała w swoim życiu narkotyków. Przy czym najpowszechniej używanym narkotykiem są przetwory konopi indyjskich - są to narkotyki używane równie często przez osoby dorosłe jak i młodzież. W roku 2014 ponad $11,7 \%$ osób młodych, od 15 do 34 roku życia, mieszkających w Europie, używało marihuany lub haszyszu, z czego 60,3\% używających konopi indyjskich to osoby w późnym okresie adolescencji i okresie wczesnej dorosłości, od 15 do 24 roku życia ${ }^{39}$.

Statystyki dotyczące używania substancji psychoaktywnych innych niż alkohol wśród polskiej młodzieży są nie mniej niepokojące. Jedna czwarta

\footnotetext{
${ }^{37}$ I. Niewiadomska, J. Chwaszcz, A. Nesterenko, Pomoc rodzinom z problemem uzależnienia od środków psychoaktywnych, w: R. KAMIŃsKI, G. PYŹLAK, J. GolEŃ (red.), Duszpasterstwo Rodzin. Refleksja naukowa i działalność pastoralna, Lublin: Wydawnictwo i Drukarnia Diecezji Rzeszowskiej 2013, s. 617-633.

${ }^{38}$ B. Hibell, U. Guttormsson, S. Ahlström, O. Balakireva, T. BJarnason, A. KoKKEVI, L. KRAUS, The 2011 ESPAD Report, s. 66-73.

39 The European Drug Report: Trends and Developments, Europe, 2015, s. 1-86.
} 
uczniów trzecich klas gimnazjum w 2011 r. przynajmniej raz w życiu paliła marihuanę lub haszysz. Zauważa się tu tendencję wzrostową zjawiska, gdyż w 2003 roku problem ten dotyczył jednej piątej uczniów trzecich klas szkół gimnazjalnych. Z kolei wśród uczniów drugich klas szkół ponadgimnazjalnych palących marihuanę lub haszysz przynajmniej raz w życiu nie zauważa się istotnych różnic w odniesieniu do danych z 2003 r. Zjawisko to dotyczy ponad $37 \%$ spośród badanych adolescentów. Charakterystyczne dla okresu adolescencji jest używanie substancji wziewnych, co z kolei nie jest już tak powszechne wśród osób dorosłych - ponad 9\% adolescentów w trzeciej klasie gimnazjum w 2011 r. przynajmniej raz używało substancji wziewnych, natomiast u uczniów drugich klas szkół ponadgimnazjalnych wskaźnik ten był niższy - dotyczył 5,6\% badanych. Najpowszechniej stosowanymi stymulantami wśród młodzieży, podobnie jak u dorosłych, jest amfetamina i kokaina. Ponad 8,3\% uczniów drugiej klasy szkoły średniej lub zawodowej kiedykolwiek w życiu brało amfetaminę, natomiast wśród uczniów klas trzecich gimnazjum wskaźnik ten był ponad połowę niższy $(4,6 \%)$. Używanie kokainy wśród uczniów trzecich klas szkół gimnazjalnych i drugich klas szkół ponadgimnazjalnych nie odbiegało znacznie - dotyczyło kolejno 3,3\% w gimnazjum oraz $3,9 \% \mathrm{w}$ szkołach ponadgimnazjalnych ${ }^{40}$.

Polska jest również jednym z krajów Unii Europejskiej z najwyższym odsetkiem młodzieży używającej „,dopalaczy”. Jest to niepokojące zjawisko ze względu na mnogość substancji psychoaktywnych w nich zawartych. Substancje te mogą mieć różnorodne działanie, ale długofalowe konsekwencje ich używania nie są do końca znane. Ponad 4\% osób badanych w późnym okresie adolescencji (od 15 do 19 roku życia) używało „dopalaczy” przynajmniej raz w życiu. Natomiast odsetek ten był wyższy wśród grupy osób od 20 do 24 roku życia - stanowił ponad $8 \%$ spośród badanych ${ }^{41}$.

Badania w grupie młodzieży uciekającej z domu wskazują na istnienie istotnych związków między używaniem alkoholu a przejawianiem innych zachowań dewiacyjnych ${ }^{42}$. Jak wskazują wyniki, w ciagu 30 dni poprzedzających badanie, $67 \%$ respondentów używało alkoholu, $52 \%$ narkotyków, ok. $44 \%$ cierpiało

\footnotetext{
40 J. SIEROSŁAWSKI, Używanie alkoholu i narkotyków przez młodzież szkolna, s. 19-37.

${ }^{41}$ A. MALCZEWSKI, A. MisiUReK, Używanie i postawy wobec substancji psychoaktywnych w populacji generalnej w 2013 roku, ,Serwis Informacyjny Narkomania” 4 (68)/2014, s. 38-43.

42 J. Kingree, R. Braithwaite, T. Wooding, Psychosocial and behavioral problems in relation to recent experience as a runway among adolescent detainees, „Criminal Justice and Behavior" 2(2001), s. 190-205.
} 
na depresję, 29\% miało uprzednie próby samobójcze ${ }^{43}$. Z kolei aż 33\% korzystało z porad psychiatrycznych i/lub leczyło się psychiatrycznie ${ }^{44}$. Stwierdzono również istnienie wzajemnych zależności między używaniem alkoholu i agresją w okresie adolescencji (badanie w ciągu okresu pięcioletniego: między 14 a 18 rokiem życia). Wzrost używania alkoholu w dłuższym okresie prowadził do zwiększenia agresji. Jednocześnie nasilenie zachowań agresywnych prowadziło do wzrostu używania alkoholu ${ }^{45}$.

Analizując literaturę przedmiotu dotyczącą czynników ryzyka używania substancji psychoaktywnych przez młodzież, można dostrzec wiele zależności pomiędzy środowiskiem sąsiedzkim a sięganiem po takie substancje. Badania z zakresu etiologii zachowań problemowych młodzieży (spożywania alkoholu, zażywania narkotyków, przestępczości i przemocy) dają podstawy do określenia kilku grup kluczowych kategorii je tłumaczących. Są nimi czynniki wychowawcze i rodzinne ${ }^{46}$, wpływ rówieśniczy ${ }^{47}$ oraz charakter sąsiedztwa ${ }^{48}$.

${ }^{43}$ M. ROTHERAM-BORUS, Suicidal behavior and risk factors among runaway youths, „American Journal of Psychiatry” 1993, nr 150, s. 103-107.

${ }^{44} \mathrm{R}$. BоOTH, Y. ZHANG, Severe aggression and related conduct problems among runaway and homeless adolescents, „Psychiatric Services” 47(1996), s. 75-80.

45 H. White, R. Loeber, M. Stouthamer-Loeber, D. Farrington, Developmental Associations between Substance Use and Violence, „Development and Psychopathology” 11(1999), s. 785-803; B. Huang, H. White, R. Kosterman, R. CAtalano, D. Hawkons, Developmental associations between alcohol and interpersonal aggression during adolescence, „Journal of Research in Crime and Delinquency” 1(2001), s. 64-83.

${ }^{46}$ S. HARVEY, C. SPIGNER, Factors associated with sexual behavior among adolescents: A multivariate analysis, „Adolescence” 30(1995), s. 253-264; T. LUSTER, S. SMALL, Factors associated with sexual risk taking behaviors among adolescents, „Journal of Marriage and the Family" 56(1994), s. 622-632; K. Miller, R. FOREHAND, B. KOTCHICK, Adolescent sexual behavior in two ethnic minority samples: The role of family variables, „Journal of Marriage and the Family" 61(1999), s. 85-98; J. TubMAn, M. WindLE, R. WINDLE, Cumulative sexual intercourse patterns among middle adolescents: Problem behavior precursors and concurrent health risk behaviors, „Journal of Adolescent Health” 18(1996), s. 182-191.

${ }^{47}$ D. Elliott, S. Menard, Delinquent friends and delinquent behavior: Temporal and developmental patterns, w: J. HAWKINS (ed.), Delinquency and crime, Cambridge 1996, s. 2867; D. HAYNIE, Delinquent peers revisited: Does network structure matter?, „American Journal of Sociology" 2001, nr 106, s. 1013-1057.

${ }^{48}$ C. CubBin, J. SANTELli, C. BRINDis, P. BRAVEMAN, Neighborhood context and sexual behaviors among adolescents: Findings from the National Longitudinal Survey of Adolescent Health, „Perspectives on Sexual and Reproductive Health” 37(2005), s. 125-134; G. BRODY, X. Ge, R. Conger, F. Gibbons, V. McBride Murry, M. Gerrard, R. Simons, The influence of neighborhood disadvantage, collective socialization, and parenting on African American children's affiliation with dewiant peers, „Child Development” 72(2001), s. 1231-1246. 
Dodatkowo warto podkreślić, że pozytywne relacje rodzinne są buforem wielu problemowych zachowań nastolatków ${ }^{49}$, w tym spożywania alkoholu i narkotyków ${ }^{50}$, przestępczości ${ }^{51}$ i przemocy ${ }^{52}$. Z kolei spędzanie czasu z dewiacyjnymi rówieśnikami wpływa na zwiększenie używania substancji psychoaktywnych $^{53}$, wzrost przestępczości i zachowań agresywnych ${ }^{54}$. Na-

${ }^{49}$ D. BAUMRIND, The influence of parenting style on adolescent competence and substance use, „Journal of Early Adolescence” 11(1991), s. 56-95; R. JESSOR, S. JESSOR, Problem behavior and psychological development: A longitudinal study of the young, New York 1977; R. JESSOR, Problem-behavior theory, psychological development, and adolescent problem drinking, „British Journal of Addiction” 82(1987), s. 331-342; G. PATTERSON, Coercive family processes, Eugene 1982, s. 41-52.

${ }^{50}$ B. Kotchick, A. Shaffer, R. Forehand, K. Miller, Adolescent sexual risk behavior: A multi-system perspective, „Clinical Psychology Review” 21(2001), s. 495-519; B. STANTON, X. Li, J. Galbraith, G. Cornick, S. Feigelman, L. Kaljee, Y. Zhou, Parental underestimates of adolescent risk behavior: A randomized, controlled trial of parental monitoring intervention, „Journal of Adolescent Health” 26(2001), s. 18-26; D. UpChurCH, C. ANESHENSEL, C. SUCOFF, L. LEVY-STORMS, Neighborhood and family contexts of adolescent sexuality, „Journal of Marriage and the Family” 61(1999), s. 920-933; D. WHITAKER, K. MiLLER, Parentadolescent discussions about sex and condoms: Impact on peer influences of sexual risk behavior, „Journal of Adolescent Research” 15(2000), s. 251-273; L. WhitBECK, K. YODER, D. HoYt, R. CONGER, Early adolescent sexual activity: A developmental study, „Journal of Marriage and the Family" 61(1999), s. 934-946.

${ }^{51}$ R. Forehand, K. Miller, R. DUtRa, M. CHANCE, Role of parenting in adolescent deviant behavior: Replication across and within two ethnic groups, „Journal of Consulting and Clinical Psychology" 65(1997), s. 1036-1041; D. GoRMAN-SMith, P. TOLAN, D. HENRY, A developmental ecological model of the relation of family functioning to patterns of delinquency, „Journal of Quantitative Criminology" 16(2000), s. 169-198; M. PAschall, C. Ringwalt, R. Flewelling, Effects of parenting, father absence, and affiliation with delinquent peers on delinquent behavior among African-American male adolescents, „Adolescence” 38(2003), s. 15-34.

52 D. Henry, P. TOlAn, D. Gorman-SMith, Longitudinal relations between community disadvantage, neighborliness, safety, and delinquency involvement. Technical Report, Chicago 1998, s. 3-11; D. Howard, L. KALJeE, L. RaChubA, S. Cross, Coping with youth violence: Assessments by minority parents in public housing, „American Journal of Health and Behavior” 27(2003), s. 483-492; A. VAZsonyi, E. Trejos-CAstillo, L. HuAng, Youth violence across ethnic and national groups: Comparison of rates and developmental processes, w: D. FLANNERY, A. VAZSONYI, I. WALDMAN (ed.), The Cambridge Handbook of Violent Behavior and Aggression, New York 2007, s. 418-430.

${ }^{53}$ K. Griffin, G. Botvin, L. Scheier, T. D1'AZ, N. Miller, Parenting practices as predictors of substance abuse, delinquency, and aggression among urban minority youth: Moderating effects of family structure and gender, „Psychology of Addictive Behaviors” 14(2000), s. 174-184; J. Williams, C. Ayers, R. Aвbott, J. Hawkins, R. Catalano, Racial differences in risk factors for delinquency and substance use among adolescents, „Social Work Research" 23(1999), s. 241-256.

${ }^{54}$ G. Barnes, J. Welte, J. Hoffman, B. DintchefF, Shared predictors of youth gambling, substance use, and delinquency, „Psychology of Addictive Behaviors” 19(2005), s. 165- 
tomiast słaba organizacja sąsiedztwa: wysoki poziom ubóstwa, różnorodność etniczna, niestabilność mieszkaniowa, wysoki poziom problemów rodzinnych, prowadzą do wzrostu używania substancji, przestępczości i przemocy, głównie z powodu słabych lub brakujących sieci międzyludzkich i kluczowych mechanizmów kontroli społecznej ${ }^{55}$.

Jedną z teorii prezentujących to zjawisko jest Teoria Zachowań Problemowych Jessorów ${ }^{56}$. Niemal cztery dekady temu R. Jessor i S. Jessor (1977) zaproponowali teorię zachowań problemowych (PBT) jako kompleksowy, wielowymiarowy model zachowań problemowych wyjaśniający dewiacyjne zachowania występujące $\mathrm{w}$ grupie adolescentów, $\mathrm{w}$ tym problem $\mathrm{z}$ alkoholem ${ }^{57}$, używanie narkotyków ${ }^{58}$, palenie papierosów, ryzykowna jazda samochodem $^{59}$ i przedwczesna aktywność seksualna ${ }^{60}$.

W ostatnich latach Jessorowie ${ }^{61}$ uzupełnili teorię PBT o trzy zestawy czynników ryzyka i trzy zestawy czynników ochronnych: modelowanie ryzykowne (niezdrowe wzorce rodzinne, rówieśnicze, szkolne i sąsiedzkie), możliwość ryzyka (ekspozycja na możliwe ryzyko, takie jak na przykład członkostwo w grupie przestępczej), skłonność do ryzyka (cechy indywidualne, takie jak: stres, depresja, niskie poczucie własnej wartości lub postrzeganie braku możliwości osiąnnięcia satysfakcjonującego życia), a także modelowanie ochronne (rodzicielskie i rówieśnicze wzorce zachowań konwencjonalnych i wzmacniających zdrowie), kon-

174; D. FISHBEIN, D. PÉREZ, A regional study of risk factors for drug use and delinquency: Sex and racial differences, „Journal of Child and Family Studies” 9(2000), s. 461-479; S. Goldstein, P. DAvis-KeAn, J. ECCLes, Parents, peers, and problem behavior: A longitudinal investigation of the impact of relationship perceptions and characteristics on the development of adolescent problem behavior, „Developmental Psychology” 41(2005), s. 401-413.

${ }^{55}$ D. OsGood, J. Chambers, Social disorganization outside the metropolis: An analysis of rural youth violence, „Criminology” 38(2000), s. 81-115.

${ }^{56}$ R. JESSOR, S. JESSOR, Problem behavior and Psychological development: A longitudinal study of the young, New York 1977.

${ }^{57}$ J. DONOVAN, R. JESSOR, Structure of problem behawior in adolescence and young adulthood, „Journal of Consulting and Clinical Psychology” 53(1985), s. 890-905.

${ }^{58}$ F. Costa, R. Jessor, M. Turbin, Q. Dong, H. ZhAng, C. WANG, The role of social contexts in adolescence: Context protection and context risk in the United States and China, „Applied Developmental Science” 9(2005), s. 67-85.

${ }^{59}$ R. JESSOR, S. JESSOR, Problem behavior and Psychological development.

${ }^{60}$ F. Costa, R. Jessor, M. Turbin, Q. Dong, H. Zhang, C. WAng, The role of social contexts in adolescence, 2005, s. 67-85.

${ }^{61}$ R. Jessor, M. Turbin, F. Costa, Q. Dong, H. Zhang, C. WANG, Adolescent problem behavior in China and the United States: A cross-national study of psychosocial protective factors, ,Journal of Research on Adolescence” 13(2003), s. 329-360. 
trola ochronna (indywidualny poziom nietolerancji zachowań dewiacyjnych, rodzicielska i rodzinna kontrola oraz sankcje, rówieśnicza i przyjacielska kontrola i sankcje, szkolna kontrola lub dezaprobata uczniów, sąsiedzka kontrola i dezaprobata), wsparcie ochronne (pomoc rodziny, rówieśników lub przyjaciół, nauczycieli lub sąsiedzka). Wszystkie te wskaźniki ryzyka oraz ochronne mają znaczenie w różnorodnych zachowaniach problemowych ${ }^{62}$.

Bazując na przytoczonych w części teoretycznej rozważaniach, a w szczególności na Teorii Zachowań Problemowych ${ }^{63}$ można sądzić, że czynnikami chroniącymi przed podejmowaniem zachowań problemowych są relacje pozytywne $\mathrm{z}$ innymi osobami ${ }^{64}$. Oprócz najbliższej rodziny i rówieśników, w szkole istotną grupą wydają się osoby z sąsiedztwa. W niniejszej pracy przyjęto założenie, że pozytywne relacje sąsiedzkie będą współwystępowały z mniejszą częstością przyjmowania substancji psychoaktywnych. Można przypuszczać, że taki kierunek zależności jest efektem trzech funkcji relacji nawiązywanych z osobami z najbliższego sąsiedztwa. Pierwsza odnosi się do wspierania młodych ludzi w sytuacjach problemowych. Druga związana jest z przyjmowaniem wzorców zachowań obowiązujących w środowisku lokalnym. Trzecia sprowadza się do kontroli, jaką sprawują sąsiedzi nad zachowaniami młodego człowieka.

\section{METODOLOGIA BADAŃ}

\subsection{Badana grupa i procedura}

Badania przeprowadzono grupowo i anonimowo wśród młodzieży przy pomocy ankieterów w wybranych miejscowościach i szkołach znajdujących się w województwie lubelskim. Zrealizowano je z wykorzystaniem metryczki oraz dwóch narzędzi kwestionariuszowych. Poszczególne szkoły i klasy były losowane w taki sposób, aby odwzorować procentową strukturę szkół z uwagi na specyficzne kryteria. Wśród nich uwzględniono: miejsce usytuowania szkoły (małe miasto/wieś i duże miasto powyżej 5 tys. mieszkańców), status szkoły (publiczna $v s$ niepubliczna), zdawalność egzaminu końcowego (powy-

\footnotetext{
${ }^{62}$ A. Vazsonyi, E. Trejos-Castillo, L. HuAng, Youth violence across ethnic and national groups, 2007, s. 418-430.

${ }^{63}$ R. Jessor, M. Turbin, F. Costa, Q. Dong, H. Zhang, C. WANG, Adolescent problem behavior in China and the United States, 2003, s. 329-360.

${ }^{64}$ I. NiEWIADOMSKA, J. CHWASZCZ, Jak skutecznie zapobiegać karierze przestępczej?, Lublin: EFS 2010, s. 119-134.
} 
żej i poniżej 50\%) oraz rodzaj szkoły (szkoła zawodowa, liceum ogólnokształcące i technikum). Przebadano łącznie 960 młodych osób.

Po wstępnym przeanalizowaniu odpowiedzi odrzucono zestawy badawcze osób nierzetelnych. Kierowano się tu dwoma kryteriami: (1) więcej niż $20 \%$ braków odpowiedzi w zastosowanych kwestionariuszach oraz (2) zaznaczenie występowania wszystkich możliwych zachowań problemowych. Po zastosowaniu tej procedury pozostawiono 918 osób. Wśród tej grupy było 485 kobiet i 433 mężczyzn w wieku od 17 do 21 lat przy średniej $\mathrm{M=18,05}$ ( $\mathrm{SD}=0,36$ ). Najsilniej reprezentowani byli mieszkańcy wsi $(57,9 \%)$. Osoby z miast do 50 tys. i miast ponad 50 tys. mieszkańców stanowiły odpowiednio: 20,1\% i $22 \%$. Przeważająca większość badanej młodzieży aktualnie mieszkała w domu rodzinnym (89\%). Jedynie $11 \%$ respondentów zamieszkiwało inne miejsca (m.in. stancja, internat). Połowa osób pochodziła z rodzin wielodzietnych $(51,9 \%)$.

\subsection{Metody}

Badanych oprócz danych metryczkowych poproszono o odniesienie się do pozycji z polskiej wersji Risk and Protective Factor Measures (RPFM) ${ }^{65}$ oraz autorskiej metody wzorowanej na Problem Behavior Syndrome Measure $(\mathrm{PBSM})^{66}$.

RPFM składa się z dwóch części. Pierwsza zawiera czynniki ochraniające. Druga odnosi się do zachowań ryzykownych. Dla celów niniejszego opracowania z metody wybrano jedynie sześć pozycji opisujących relacje z sąsiadami (np. Przyjaźnie i znajomości z ludźmi z mojego sqsiedztwa wiele dla mnie znacza) zaliczane do czynników ochraniających. Poszczególne twierdzenia oceniane były na czterostopniowej skali od A - zdecydowanie nie zgadzam się do D - zdecydowanie zgadzam się. Wynikiem jest suma punktów. Im wyższy wynik w tej metodzie, tym relacje sąsiedzkie lepsze, a osoby badane bardziej w nie zaangażowane. Rzetelność wymiaru utworzonego z wybranych twierdzeń była zadowalająca i wynosiła alfa Cronbaha $=0,89$.

$\mathrm{Z}$ kolei do pomiaru zachowań problemowych zastosowano eksperymentalną wersję Skali Zachowań Problemowych wzorowaną na PBSM. Metoda zawiera 39 twierdzeń opisujących na skali od A - nie/nigdy do E - 6 razy lub więcej

\footnotetext{
${ }^{65}$ A.T. Vazsonyi, P. Chen, D.D. Jenkins, E. Burcu, G. Torrente, Ch.-J. Sheu, Jessor's problem behavior theory: Cross-national evidence from Hungary, the Netherlands, Slovenia, Spain, Switzerland, Taiwan, Turkey, and the United States, „Developmental Psychology” 46(2010), nr 6, s. 1779-1791.

66 Tamże.
} 
częstość występowania zachowań problemowych. W stosunku do oryginalnej wersji metody uzupełniono ją o szereg nowych pozycji. Mając na uwadze problem badawczy artykułu, do analiz wybrano jedynie 9 kategorii mierzących częstość przyjmowania substancji psychoaktywnych (np. Czy kiedykolwiek ... paliteś papierosy?). Wyniki analizy czynnikowej przeprowadzone w badanej próbie wykazały, że pozycje te można podzielić na dwa wymiary: legalne środki psychoaktywne (alkohol oraz papierosy; 6 pozycji) i nielegalne środki psychoaktywne (marihuana, dopalacze, inne narkotyki, takie jak m.in. amfetamina i ekstazy; 3 pozycje). Uzyskane rozwiązanie czynnikowe wyjaśnia $73,4 \%$ wariancji mierzonego konstruktu. Oba wyodrębnione wymiary maja zadowalającą rzetelność odpowiednio: alfa Cronbacha ${ }_{w 1}=0,91$ i alfa Cronba$\mathrm{cha}_{\mathrm{w} 2}=0,81$. Wynikiem $\mathrm{w}$ metodzie jest suma punktów przyznawanych za występowanie konkretnego rodzaju zachowań problemowych niezależnie od stopnia jego nasilenia. Oprócz miar parcjalnych (legalne i nielegalne substancje psychoaktywne) narzędzie pozwala również na obliczenie wyniku globalnego - substancje psychoaktywne (WO). Za legalne substancje psychoaktywne uznano te dostępne zgodnie $\mathrm{z}$ polskim prawem $\mathrm{w}$ oficjalnej sprzedaży. Jako nielegalne substancje psychoaktywne traktowano takie, które są w Polsce zakazane.

\subsection{Wyniki}

Właściwą eksplorację danych przeprowadzono z wykorzystaniem pakietu IBM SPSS Statistics v. 22. Punktem wyjścia w analizach było sprawdzenie siły związku pomiędzy relacjami sąsiedzkimi a częstością przyjmowania substancji psychoaktywnych (por. tabela 1). Wykazano, że w całej badanej grupie jedynie częstość przyjmowania legalnych substancji psychoaktywnych koreluja z poziomem relacji sąsiedzkich. Związek ten był ujemny, a jego siła bardzo słaba. W dwóch pozostałych wymiarach Skali Zachowań Problemowych współczynniki okazały się nieistotne statystycznie.

$\mathrm{Z}$ uwagi na bardzo niską siłę związku pomiędzy analizowanymi zmiennymi zdecydowano się na podzielenie badanej grupy młodzieży na dwie podgrupy: osoby nieużywające środków psychoaktywnych oraz osoby przyjmujące środki psychoaktywne. Podziału dokonano na podstawie wyników Skali Zachowań Problemowych. Pierwszą wyodrębnioną podgrupę $(\mathrm{N}=133)$ stanowiły osoby, które otrzymały w niej wynik równy zero. Z kolei drugą $(\mathrm{N}=785)$ stanowili badani otrzymujący jeden lub więcej punktów, czyli tacy, którzy wskazali na przyjmowanie jakiejkolwiek legalnej lub nielegalnej substancji psychoaktywnej. 
Tab. 1. Statystyki opisowe i współczynniki korelacji r-Pearsona dla analizowanych zmiennych (dla całej badanej grupy $\mathrm{N}=918$ )

\begin{tabular}{|c|l|c|c|c|c|c|c|c|}
\hline L.p. & \multicolumn{1}{|c|}{ Zmienna } & Min. & Maks. & M & SD & $(1)$ & (2) & (3) \\
\hline 1 & Relacje sąsiedzkie & 6 & 24 & 15,71 & 4,51 & & & \\
\hline 2 & $\begin{array}{l}\text { Legalne substancje } \\
\text { psychoaktywne }\end{array}$ & 0 & 6 & 3,29 & 1,94 & 0,011 & & \\
\hline 3 & $\begin{array}{l}\text { Nielegalne substancje } \\
\text { psychoaktywne }\end{array}$ & 0 & 3 & 0,51 & 0,81 &,$- 090^{* *}$ &, $438 * *$ & $\begin{array}{l}\text { (Substancje } \\
\text { psychoaktywne (WO) }\end{array}$ \\
\hline 4 & 9 & 3,80 & 2,40 & $-0,021$ &, $953 * *$ &, $689 * *$ \\
\hline
\end{tabular}

$* * \mathrm{p}<0.01$

Wyodrębnione grupy porównano w zakresie wyników obrazujących jakość relacji sąsiedzkich (por. tabela 2). Zestawienie to ujawniło występowanie znaczącej tendencji statystycznej. Co ciekawe, była ona inna, niż wstępnie zakładano. Zgodnie z nią, osoby nieużywające środków psychoaktywnych cechują się lepszymi kontaktami sąsiedzkimi, niż te przyjmujące takie środki.

Tab. 2. Różnice w relacjach sąsiedzkich u osób używających i nieużywających środków psychoaktywnych - wyniki testu t-studenta

\begin{tabular}{|l|c|c|c|c|c|c|}
\hline \multirow{3}{*}{ Zmienna } & \multicolumn{2}{|c|}{ Nieużywający } & \multicolumn{2}{|c|}{ Używający } & \multirow{2}{*}{$\mathrm{t}$} & \multirow{2}{*}{$\mathrm{p}$} \\
\cline { 2 - 5 } & środków psychoaktywnych & środki psychoaktywne & $\mathrm{M}$ & & \\
\cline { 2 - 6 } & $\mathrm{M}$ & $\mathrm{SD}$ & $\mathrm{M}$ & $\mathrm{SD}$ \\
Relacje & 15,03 & 5,43 & 15,82 & 4,33 & 1,88 & 0,06 \\
\hline
\end{tabular}

Ocena związku pomiędzy relacjami sąsiedzkimi a używaniem substancji psychoaktywnych w podgrupie korzystającej z tego typu substancji wykazała, podobnie jak w pierwszym zestawieniu, korelacje negatywne z substancjami nielegalnymi (por. tabela 3). Dodatkowo uzyskano jednak statystycznie istotny związek relacji sąsiedzkich z globalnym wskaźnikiem korzystania z substancji psychoaktywnych. Pozytywne relacje sąsiedzkie współwystępują z mniejszą częstością przyjmowania nielegalnych substancji. Nadal jednak siła uzyskanych powiązań okazała się bardzo niska, co może sugerować, że relacja ta jest moderowana przez inne zmienne. 
Tab. 3. Związek pomiędzy relacjami sąsiedzkimi

a używaniem substancji psychoaktywnych w grupie osób używających takich substancji (r-Pearsona, $\mathrm{N}=785$ )

\begin{tabular}{|c|l|c|c|c|c|c|c|c|}
\hline L.p. & \multicolumn{1}{|c|}{ Zmienna } & Min. & Maks. & M & SD & $(1)$ & (2) & (3) \\
\hline 1 & Relacje sąsiedzkie & 6,00 & 24,00 & 15,82 & 4,33 & & & \\
\hline 2 & Legalne substancje psy- & 0,00 & 6,00 & 3,85 & 1,49 &,- 051 & & \\
\hline 3 & Nielegalne substancje & 0,00 & 3,00 &, 592 & 0,84 &,$- 124^{* *}$ & & \\
\hline 4 & Substancje psychoaktywne & 1,00 & 9,00 & 4,44 & 1,97 &,$- 092^{*}$ &, $918^{* *}$ &, $711^{* * *}$ \\
\hline
\end{tabular}

$* \mathrm{p}<0,05, * * \mathrm{p}<0.01$

W toku dalszych analiz podjęto próbę sprawdzenia, jak siła związku pomiędzy analizowanymi zmiennymi będzie modyfikowana przez podstawowe zmienne socjodemograficzne, jak płeć, miejsce pochodzenia i aktualne miejsce zamieszkania (wspólnie z rodzicami vs stancja/internat). W przypadku dwóch pierwszych zmiennych nie odnotowano różnic w zakresie siły związku między relacjami sąsiedzkimi a przyjmowaniem substancji psychoaktywnych. Ciekawą zależność odnotowano w przypadku podziału badanych osób na podgrupę osób zamieszkujących z rodzicami i poza domem rodzinnym (por. tabela 4).

Tab. 4. Związek pomiędzy relacjami sąsiedzkimi a używaniem substancji psychoaktywnych w grupie osób używających substancji mieszkających w domu lub poza nim - współczynnik korelacji r-Pearsona)

\begin{tabular}{|c|c|c|c|c|c|c|c|c|}
\hline & Min. & Maks. & M & SD & (1) & (2) & (3) \\
\hline \multicolumn{9}{|c|}{ Osoby mieszkające z rodzicami $(\mathrm{N}=730)$} \\
\hline 1 & Relacje sąsiedzkie & 6 & 24 & 15,86 & 4,39 & & & \\
\hline 2 & Legalne substancje psychoak- & 0 & 6 & 3,85 & 1,47 &,$- 084^{*}$ & & \\
\hline 3 & Nielegalne substancje psy- & 0 & 3 & 0,57 & 0,83 &,$- 125^{* *}$ &, $374^{* *}$ & \\
\hline 4 & Substancje psychoaktywne & 1 & 9 & 4,42 & 1,94 &,$- 117^{* *}$ &, $918^{* *}$ &, $711^{* * *}$ \\
\hline \multicolumn{9}{|c|}{ Osoby mieszkające poza domem $(\mathrm{N}=87)$} \\
\hline 1 & Relacje sąsiedzkie & 6 & 24 & 15,54 & 3,94 & & & \\
\hline 2 & Legalne substancje psycho- & 0 & 6 & 3,87 & 1,74 &, $232^{*}$ & & \\
\hline 3 & Nielegalne substancje psycho- & 0 & 3 & 0,75 & 0,95 &,- 123 &, $359^{* *}$ & \\
\hline 4 & Substancje psychoaktywne & 1 & 9 & 4,62 & 2,27 &, 127 & ,920** &, $696^{* *}$ \\
\hline
\end{tabular}

$* \mathrm{p}<0,05, * * \mathrm{p}<0.01$ 
Wśród osób zamieszkujących z rodzicami odnotowano słabe, choć statystycznie istotne korelacje pomiędzy relacjami sąsiedzkimi a wszystkimi wymiarami odnoszącymi się do używania substancji psychoaktywnych. Charakter tego powiązania był ujemny. Pozytywne relacje sąsiedzkie współwystępuja z niższą częstością przyjmowania substancji psychoaktywnych, zarówno tych legalnych, jak i nielegalnych.

Natomiast w przypadku osób mieszkających poza domem rodzinnym wystąpił tylko jeden statystycznie istotny związek. Dotyczy on relacji sąsiedzkich i korzystania z legalnych substancji psychoaktywnych. Siła tego powiązania jest znacząco wyższa, niż w kategoriach opisanych powyżej. Interesujący jest również fakt, że korelacja ta ma przeciwny kierunek, niż w zakresie wcześniej opisanych współczynników. Zgodnie z otrzymanymi wynikami, u osób mieszkających poza domem pozytywne relacje sąsiedzkie współwystępują z częstszym przyjmowaniem legalnych środków psychoaktywnych. Testy istotności różnic dla współczynników korelacji, obliczone między wyodrębnionymi podgrupami, wykazały dwie znaczące różnice (por. wykres 1).

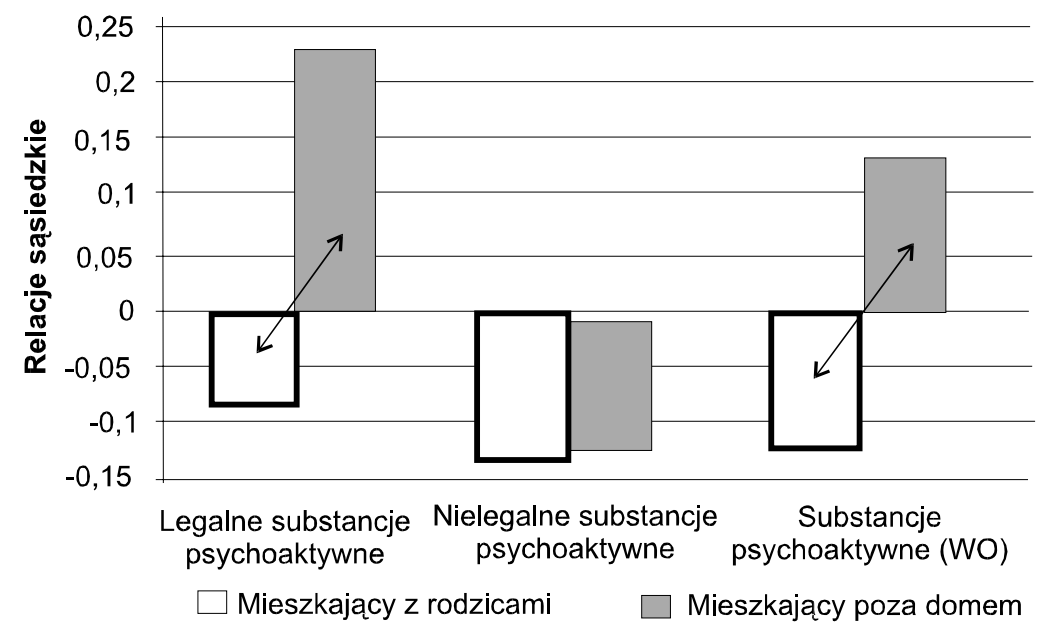

Wykres 1. Różnice w sile związku pomiędzy relacjami sąsiedzkimi a używaniem wybranych substancji psychoaktywnych - porównanie osób mieszkających z rodzicami i poza domem (strzałkami oznaczono różnice istotne statystycznie na poziomie $\mathrm{p}<0,05$ )

Dotyczą one powiązań relacji sąsiedzkich z: (1) częstością używania legalnych substancji psychoaktywnych oraz (2) globalnym wskaźnikiem korzystania z substancji odurzających. Uzyskane współczynniki wskazują, że występu- 
je zupełnie inny charakter związku pomiędzy stosowaniem legalnych substancji psychoaktywnych a relacjami sąsiedzkimi u młodzieży mieszkającej z rodzicami i poza domem rodzinnym.

\subsection{Podsumowanie i dyskusja wyników}

W przeprowadzonych na potrzeby niniejszego artykułu badaniach ujawniono, że generalnie wysoki kapitał społeczny, w postaci pozytywnych relacji sąsiedzkich, współwystępuje z rzadszym przyjmowaniem substancji psychoaktywnych. Można zatem przypuszczać, że pozytywne relacje społeczne nawiązywane w najbliższym otoczeniu chronią młodego człowieka przed podejmowaniem różnego rodzaju zachowań problemowych, w tym korzystaniem ze środków odurzających. Taki układ wyników jest spójny z Teorią Zachowań Problemowych i opisanych w niej zestawach czynników ochronnych ${ }^{67}$. Prawdopodobnie w przypadku wpływu relacji sąsiedzkich największy udział w unikaniu/redukowaniu zachowań problemowych ma kontrola ochronna i wsparcie ochronne. Dzięki nim młody człowiek wie, jakiego rodzaju zachowania są aprobowane w danym miejscu i czasie. Dodatkowo, towarzyszy mu świadomość, że w przypadku trudności może liczyć na osoby starsze, które go wesprą emocjonalnie, ale także doradzą, bazując na doświadczeniach życiowych, konkretne sposoby rozwiązania problemów.

Uzyskane wyniki na próbie młodzieży z województwa lubelskiego wskazują jednak na bardzo słabą zależność między relacjami sąsiedzkimi a korzystaniem ze środków psychoaktywnych. Prawdopodobnie wytłumaczenie tego faktu może być dwojakie. $Z$ jednej strony, niewielki związek relacji sąsiedzkich z zachowaniami problemowymi może być pochodną zmian społecznych oraz modyfikacji we wzorcach relacji zachodzących w otoczeniu. Już od wielu lat widoczny jest coraz głębszy spadek siły powiązań i zależności między mieszkańcami miejscowości, osiedli. Dominuje w nich anonimowość i brak tendencji do wchodzenia w zażyłe relacje. Potwierdzają to badania sondażowe wskazujące, że większość Polaków zachowuje dystans w relacjach sąsiedzkich i aż jedna czwarta deklaruje, że wśród sąsiadów nie zna nikogo, z kim utrzymywałaby kontakty towarzyskie ${ }^{68}$. Innym potwierdzeniem słabe-

${ }^{67}$ Por. R. Jessor, M. Turbin, F. Costa, Q. Dong, H. Zhang, C. Wang, Adolescent problem behavior in China and the United States, 2003, s. 329-360; A.T. VAZSONYI, P. CHEN, D.D. Jenkins, E. BurCu, G. TORRENTE, Ch.-J. SHEU, Jessor's problem behavior theory, s. $1779-1791$.

${ }^{68}$ K. KowalczuK, Kontakty z sqsiadami $i$ inne więzi społeczne. Komunikat $z$ badań CBOS, Warszawa, BS/93/2012. 
go wpływu relacji sąsiedzkich na zachowania młodych ludzi mogą być wyniki badań, w których wykazano, że osoby młode, do 20 roku życia, zamieszkujące $w$ blokach oraz zabudowie jednorodzinnej preferują typ relacji sąsiedzkich sentymentalno-rytualny, cechujący się ograniczeniem kontaktów do minimum społecznego zaangażowania, co przejawia się w okazjonalnym niesieniu wzajemnej pomocy i wymianie grzeczności ${ }^{69}$. Tak rozumiane sąsiedztwo jest relacją, która zapewnia namiastkę poczucia bezpieczeństwa nie ograniczając przy tym swobody jednostki, ale i nie stanowiąc znaczącego czynnika wpływającego na zachowanie młodego człowieka ${ }^{70}$.

$\mathrm{Z}$ drugiej strony, młodzi ludzie, co jest zrozumiałe $\mathrm{z}$ punktu widzenia rozwoju osobniczego, mają tendencję do częstszego nawiązywania relacji z grupą rówieśniczą niż osobami starszymi. W myśl teorii Jessorów ${ }^{71}$ to relacje rówieśnicze w okresie adolescencji są dominujące przy podejmowaniu decyzji, minimalizując jednocześnie rolę rodziców. Od innych młodych osób czerpane sa wzorce i przejmowane standardy zachowania. Taka grupa jest dla młodzieży bardziej atrakcyjna, chcą uzyskać jej akceptację. Potwierdzają to również badania zaprezentowane w niniejszym artykule. Dowodem na to jest pozytywny związek relacji sąsiedzkich ze stosowaniem legalnych substancji psychoaktywnych (tytoń, alkohol) w grupie młodzieży mieszkającej poza domem rodzinnym. Wynik ten sugeruje również, że dobre relacje sąsiedzkie moga pełnić nie tylko rolę czynników ochraniających, ale również przyczyniających się do przejawiania zachowań niewłaściwych. W przypadku młodych ludzi może to być częste i spowodowane nadmierną chęcią uzyskania aprobaty ze strony otoczenia rówieśniczego. Taki stan rzeczy jest szczególnie prawdopodobny w sytuacji, gdy młody człowiek wchodzi w nowe środowisko, poznaje nowych ludzi i pozbawiony jest kontroli rodzicielskiej. Próbując uzyskać akceptację, może rezygnować ze wzorców wyniesionych z rodziny pochodzenia i decydować się na standard funkcjonowania typowy dla nowego miejsca i nowych osób.

Uzyskane wyniki są spójne z dotychczasowymi ustaleniami dostępnymi w literaturze przedmiotu. Siła powiązań jest jednak stosunkowo słaba, co

${ }^{69}$ A. BuJWICKA, Typy wielkomiejskiego sasiedztwa wyobrażone a praktykowane stosunki sqsiedzkie mieszkańców Lodzi, „Acta Universitatis Lodziensis. Folia Sociologica” 36(2011), s. 101-119.

${ }^{70}$ I. NIEWIADOMSKA, M. KALINOWSKI, Skazani na wykluczenie!? Zasoby adaptacyjne osób zagrożonych marginalizacja spoteczna, Lublin 2010, s. 619.

${ }^{71}$ R. JESSOR, Risk Behavior in Adolescence: A Psychological Framework for Understanding and Action, ,Journal of Adolescent Health” 12(1991), s. 597-605. 
może być efektem szeregu specyficznych cech przeprowadzonych badań. Do głównych zaliczyć można samą ich problematykę oraz specyfikę badanej grupy. Podjęta tematyka, szczególnie kategoria zachowań problemowych jest szczególnie narażona na zniekształcenia odpowiedzi w metodach samoopisowych z powodu wpływu zmiennej aprobaty społecznej. Młodzi ludzie pomimo zapewniania anonimowości mogą obawiać się konsekwencji podawania rzeczywistych odpowiedzi. Paradoksalnie mogą również zaznaczać odpowiedzi przeszacowujące występowanie zachowań problemowych, aby nie różnić się od rówieśników.

Planując dalsze badania dotyczące relacji sąsiedzkich i występowania zachowań problemowych u młodzieży, warto zwrócić uwagę na kilka ważnych elementów. Interesujące byłoby dalsze zgłębienie wykrytych różnic pomiędzy młodzieżą zamieszkującą w domach rodzinnych i poza nimi, przy zwiększeniu liczebności osób badanych grup oraz uchwyceniu specyfiki oddziaływania środowiska rodzinnego i rówieśniczego. Ważne wydaje się również sprawdzenie, z jakimi konkretnie osobami nawiązywane są relacje sąsiedzkie, jakiego typu są to relacje i jakich zachowań dotyczą. Cenne byłoby również wykorzystanie wielowymiarowych narzędzi pozwalających na bardziej wnikliwą analizę kategorii kapitału społecznego. Ciekawe mogłoby być również wprowadzenie specyficznych moderatorów związku między relacjami sąsiedzkimi a podejmowaniem zachowań problemowych. Wśród nich warto byłoby kontrolować np. specyfikę miejsca pochodzenia, wydolność wychowawczą rodziny, system wparcia dostępny w miejscu zamieszkania, warunki materialne oraz wzorce rodzinne w obszarze zachowań związanych z przyjmowaniem substancji psychoaktywnych.

\section{BIBLIOGRAFIA}

Anderson P., Baumberg B., A Public Health Perspective. Alcohol in Europe, London: Institute of Alcohol Studies for the European Commission 2006.

BARCZYKOWSKA A., Kapitał społeczny a zjawiska patologii społecznej w wielkim mieście, Kraków: Oficyna Wydawnicza „Impuls” 2011.

Barnes G., Welte J., Hoffman J., Dintcheff B., Shared predictors of youth gambling, substance use, and delinquency, „Psychology of Addictive Behaviors” 19(2005), s. 165-174.

BAUMRIND D., The influence of parenting style on adolescent competence and substance use, „Journal of Early Adolescence” 11(1991), s. 56-95.

BednareK-SzcZePańsKa M., Wiejski kapitał społeczny we współczesnej Polsce. Przegląd badań i uwagi metodyczne, „Acta Universitatis Lodziensis. Folia Geographica Socio-Economica” 13(2013), s. 19-40. 
BŁASZCZYK M., O więzi sąsiedzkiej w środowisku wielkomiejskim - na przykładzie Wrocławia, w: I. Borowik, K. SzTAlta (red.), Współczesna socjologia miasta. Wielość oglądów i kierunków badawczych dyscypliny, Wrocław: Wydawnictwo Uniwersytetu Wrocławskiego 2007, s. 155-169.

BOOTH R., ZHANG Y., Severe aggression and related conduct problems among runaway and homeless adolescents, „Psychiatric Services” 47(1996), s. 75-80.

Brody G., Ge X., Conger R., Gibbons F., McBride Murry V., Gerrard M., Simons R., The influence of neighborhood disadvantage, collective socialization, and parenting on African American children's affiliation with deviant peers, „Child Development” 72(2001), s. 1231-1246.

BRUHN J., Efekt grupy. Spójność społeczna i jej konsekwencje dla zdrowia, Warszawa: Wydawnictwo SWPS Academica 2001.

BUJWICKA A., Typy wielkomiejskiego sąsiedztwa wyobrażone a praktykowane stosunki sąsiedzkie mieszkańców Łodzi, „Acta Universitatis Lodziensis. Folia Sociologica” 36(2011), s. 101-119.

Coleman J., Foundations of Social Theory, Cambridge: Belknap Press 1990.

Costa F., Jessor R., Turbin M., Dong Q., Zhang H., WAng C., The role of social contexts in adolescence: Context protection and context risk in the United States and China, „Applied Developmental Science" 9(2005), s. 67-85.

Cubbin C., Santelli J., Brindis C., Braveman P., Neighborhood context and sexual behaviors among adolescents: Findings from the National Longitudinal Survey of Adolescent Health, „Perspectives on Sexual and Reproductive Health” 37(2005), s. 125-134.

DONOVAN J., JESSOR, R., Structure of problem behawior in adolescence and young adulthood, „Journal of Consulting and Clinical Psychology” 53(1985), s. 890-905.

DunCan S.C., Duncan, T.E., STRYCher A.L., A multilevel analysis of neighborhood context and youth alcohol and drug problems, ,Prevention Science” 3(2)/2002, s. 125-133.

Duncan T.E., Duncan S.C., OKut H., Strycher A.L., HiX-Small H., A multilevel contextual model of neighborhood collective efficacy, „American Journal of Community Psychology" 32(3/4)/2003, s. 245-252.

Elliott D., Menard, S., Delinquent friends and delinquent behavior: Temporal and developmental patterns, w: J. Hawkins (ed.), Delinquency and crime, Cambridge 1996, s. 28-67.

FEDYSZAK-RADZIEJOWSKA B., Kapitał społeczny wsi - w poszukiwaniu utraconego zaufania, w: K. SzAFraniec (red.), Kapitał ludzki i zasoby społeczne wsi. Ludzie - społeczność lokalna - edukacja, Warszawa: Instytut Rozwoju Wsi i Rolnictwa Polskiej Akademii Nauk 2006, s. 71-120.

FISHBEIN D., PEREZ D., A regional study of risk factors for drug use and delinquency: Sex and racial differences, ,Journal of Child and Family Studies” 9(2000), s. 461-479.

Forehand R., Miller K., Dutra R., Chance M., Role of parenting in adolescent deviant behavior: Replication across and within two ethnic groups, „Journal of Consulting and Clinical Psychology" 65(1997), s. 1036-1041.

Goldstein S., DAVIS-KeAN, P., ECCles J., Parents, peers, and problem behavior: A longitudinal investigation of the impact of relationship perceptions and characteristics on the development of adolescent problem behavior, „Developmental Psychology” 41(2005), s. 401-413.

Gorman-Smith D., Tolan P., Henry D., A developmental ecological model of the relation of family functioning to patterns of delinquency, ,Journal of Quantitative Criminology” 16(2000), s. 169-198.

Griffin K., Botvin G., Scheier L., DíAZ T., Miller N., Parenting practices as predictors of substance abuse, delinquency, and aggression among urban minority youth: Moderating 
effects of family structure and gender, „Psychology of Addictive Behaviors” 14(2000), s. $174-184$.

Gudmundsson G., MiKIEwICZ P., Koncepcja kapitału społecznego i jej możliwe użycie w badaniach porównawczych zmierzających do wsparcia reform edukacyjnych, w: P. MIKIEWICZ (red.), Kapitał społeczny i edukacja. Badanie porównawcze pomiędzy Polską i Islandia. Raport podsumowujący, Wrocław: Dolnośląska Szkoła Wyższa 2011, s. 12-31.

Hanifan L.J., The Rural School Community Center, „Annals of the American Academy of Political and Social Science" 67(1916), s. 130-138.

HARVEY S., SPIGNER C., Factors associated with sexual behavior among adolescents: A multivariate analysis, „Adolescence” 30(1995), s. 253-264.

HAYNIE D., Delinquent peers revisited: Does network structure matter?, „American Journal of Sociology" 2001, nr 106, s. 1013-1057.

Henry D., Tolan P., Gorman-Smith D., Longitudinal relations between community disadvantage, neighborliness, safety, and delinquency involvement. Technical Report, Chicago 1998, s. $3-11$.

Hibell B., Guttormsson U., Ahlström S., Balakireva O., Bjarnason T., KokKevi A., Kraus L., The 2011 ESPAD Report. Substance Use Among Students in 36 European Countries, Stockholm 2012, s. 66-73.

Howard D., Kaljee L., Rachuba L., Cross S., Coping with youth violence: Assessments by minority parents in public housing, „American Journal of Health and Behavior" 27(2003), s. 483-492.

Huang B., White H., Kosterman R., Catalano R., Hawkons D., Developmental associations between alcohol and interpersonal aggression during adolescence, ,Journal of Research in Crime and Delinquency" 1(2001), s. 64-83.

JESSOR R., JESSOR S., Problem behavior and psychological development: A longitudinal study of the young, New York 1977.

JESSOR R., Problem-behavior theory, Psychological development, and adolescent problem drinking, „British Journal of Addiction” 82(1987), s. 331-342.

Jessor R., Risk Behavior in Adolescence: A Psychological Framework for Understanding and Action, „Journal of Adolescent Health” 12(1991), s. 597-605.

Jessor R., Turbin M., Costa F., Dong Q., Zhang H., Wang C., Adolescent problem behavior in China and the United States: A cross-national study of psychosocial protective factors, „Journal of Research on Adolescence” 13(2003), s. 329-360.

Kaltenberg-KwiatKowsKa E., Sąsiedztwo we współczesnym mieście - stereotypy i rzeczywistość, w: W. MiszTal, J. STYK (red.), Stare i nowe struktury społeczne w Polsce, t. III: Czynniki miastotwórcze w okresach wielkich zmian społecznych, Lublin: Wydawnictwo Uniwersytetu Marii Curie-Skłodowskiej 2002, s. 253-280.

KELLEY P., The dangerousness of youth-at-risk: The possibillities of surveillance and intervention in uncertain times, „Journal of Adolescence” 23(2000), s. 463-476.

Kingree J., Braithwaite R., Wooding T., Psychosocial and behavioral problems in relation to recent experience as a runway among adolescent detainees, „Criminal Justice and Behavior" 2(2001), s. 190-205.

Kotchick B., Shaffer A., Forehand R., Miller K., Adolescent sexual risk behavior: A multi-system perspective, „Clinical Psychology Review” 21(2001), s. 495-519.

KowalczuK K., Kontakty z sąsiadami i inne więzi społeczne. Komunikat z badań CBOS, Warszawa, BS/93/2012.

KRYCZKA P., Społeczność osiedla mieszkaniowego w wielkim mieście. Ideologie i rzeczywistość, Warszawa: PWN 1981. 
KRZYSZTOFEK K., Wirtualna reterytorializacja:czy istnieje lokalność w cyberprzestrzeni?, w: J. KURCZEWSKA (red.), Oblicza lokalności. Ku nowym formom życia lokalnego, Warszawa: Wydawnictwo IFiS PAN 2008, s. 391-414.

LAVERY B., Siegel A.W., Adolescent risk - taking: An analysis of problem behaviors in problem children, ,Journal of Experimental Child Psychology” 55(1993), s. 277-294.

LEWICKA M., Ways to make people active: The role of place attachment, cultural capital, and neighbourhood ties, ,Journal of Environmental Psychology” 25(2005), s. 381-395.

Łukowski W., GrygorczyK M., Henzler P., Iwaniak A., Sekutowicz K., Sąsiedztwa i mikroorganizacje w polskiej przestrzeni społecznej - próba diagnozy i rekomendacj, Warszawa: Stowarzyszenie CAL Instytut Radliński 2009.

LUSTER T., SMALL S., Factors associated with sexual risktaking behaviors among adolescents, „Journal of Marriage and the Family” 56(1994), s. 622-632.

MALCZEwSKi A., MisiUREK A., Używanie i postawy wobec substancji psychoaktywnych w populacji generalnej w 2013 roku, ,Serwis Informacyjny Narkomania” 4 (68)/2014, s. 38-43.

MigaŁA P., Wybrane elementy patologii społecznej w aspekcie ich uwarunkowań, Józefów: Wydawnictwo Wyższej Szkoły Gospodarki Euroregionalnej 2011.

Miller K., Forehand R., KotChick B., Adolescent sexual behavior in two ethnic minority samples: The role of family variables, „Journal of Marriage and the Family” 61(1999), s. 85-98.

NiEWIADOMSKA I., ChWASZCZ J., Jak skutecznie zapobiegać karierze przestępczej?, Lublin 2010, s. 119-134.

Niewiadomska I., Chwaszcz J., Nesterenko A., Pomoc rodzinom z problemem uzależnienia od środków psychoaktywnych, w: R. KAMIŃsKi, G. PYŹLAK, J. GOLEŃ (red.), Duszpasterstwo Rodzin. Refleksja naukowa i działalność pastoralna, Lublin: Wydawnictwo i Drukarnia Diecezji Rrzeszowskiej 2013, s. 617-633.

NiEWIADOMSKA I., Funkcje zasobów społecznych w działalności profilaktycznej, w: I. NIEWIADOMSKA M. KALINOWSKI (red.), Wezwani do działania. Zasoby społeczne w profilaktyce zachowań destrukcyjnych, Lublin 2010, s. 47-66.

NIEWIADOMSKA I., Innowacyjny Program Integralny P III. AUCTORIZO LIBERTAS Model wczesnej interwencji socjalnej. Program profilaktyczny (interwencyjny) zapobiegający zachowaniom autodestrukcyjnym u młodzieży o podwyższonym ryzyku uzależnienia od substancji psychoaktywnych (P III. zawierający K1-K10), Lublin 2013, s. 9.

NIEWIADOMSKA I., KALINOWSKI M., Skazani na wykluczenie!? Zasoby adaptacyjne osób zagrożonych marginalizacją społeczną, Lublin 2010, s. 619.

NIEWIADOMSKA I., Kariera przestępcza a subkultury młodzieżowe, w: E. RUSINIAK (red.), Ograniczenie przestępczości i aspołecznych zachowań „Razem bezpieczniej”. Działania resortu spraw wewnętrznych i administracji oraz innych podmiotów współpracujących na rzecz porządku publicznego oraz przeciwdziałania patologiom społecznym, Warszawa: Ministerstwo Spraw Wewnętrznych i Administracji, Komenda Główna Policji 2007, s. 118-129.

NIEWIADOMSKA I., Osobowościowe uwarunkowania skuteczności kary pozbawienia wolności, Lublin 2007, s. 269-273.

NIEWIADOMSKA I., Zakorzeniania społeczne więźniów, Lublin 2011, s. 175-197.

OSGOOD D., ChAmBers J., Social disorganization outside the metropolis: An analysis of rural youth violence, „Criminology” 38(2000), s. 81-115.

Paschall M., Ringwalt C., Flewelling R., Effects of parenting, father absence, and affiliation with delinquent peers on delinquent behavior among African-American male adolescents, ,Adolescence” 38(2003), s. 15-34.

PATTERSON G.R., Coercive family processes, Eugene: Castilia 1982, s. 41-52. 
Putnam, R.D., Samotna gra w kręgle. Upadek i odrodzenie wspólnot lokalnych w Stanach Zjednoczonych, Warszawa: Wydawnictwa Akademickie i Profesjonalne 2008.

ROTHERAM-Borus M., Suicidal behavior and risk factors among runaway youths, „American Journal of Psychiatry" 1993, nr 150, s. 103-107.

SAMPSON R.J., The neighborhood context of well-being, „Perspectives in Biology and Medicine" 46(2003), s. 553-564.

SIEROCIŃSKA K., Kapitał społeczny. Definiowanie, pomiar i typy, „Studia Ekonomiczne” 1(LXVIII)/2011, s. 69-86.

SIEROSŁAWSKI J., Używanie alkoholu i narkotyków przez młodzież szkolną. Raport z ogólnopolskich badań ankietowych zrealizowanych w 2011 r., Warszawa 2011, s. 19-37.

Stanton B., Li X., Galbraith J., Cornick G., Feigelman S., Kaljee L., Zhou Y., Parental underestimates of adolescent risk behavior: A randomized, controlled trial of parental monitoring intervention, „Journal of Adolescent Health” 26(2001), s. 18-26.

STRZESZEWSKI M., Kontakty sąsiedzkie w miejscu zamieszkania. Komunikat z badań, Warszawa: Centrum Badania Opinii Społecznej 2008.

SZCZEPAŃSKA M., Osiedla grodzone: świadomościowe aspekty podziałów społeczno-przestrzennych i wieź sąsiedzka, www.socialspacejournal.eu 2012 [data pobrania: 23.05.2015].

The European Drug Report: Trends and Developments, Europe 2015, s. 1-86.

TORUŃCZYK-RUIZ S., Znaczenie sąsiedztwa i koncentracji przestrzennej, „Biuletyn Migracyjny” 44(2013), s. 1-2.

Tubman J., Windle M., Windle R., Cumulative sexual intercourse patterns among middle adolescents: Problem behavior precursors and concurrent health risk behaviors, „Journal of Adolescent Health" 18(1996), s. 182-191.

TUROwSKI J., Kształtowanie się zbiorowości osiedlowej w wielkim mieście, „Studia Socjologiczne" 1(1976), s. 20-32.

UpChURCH D., ANESHENSEl C., SUCOFF C., LEVY-STORMS L., Neighborhood and family contexts of adolescent sexuality, „Journal of Marriage and the Family” 61(1999), s. 920-933.

Vazsonyi A.T., Chen P., Jenkins D. Dusty, Burcu E., Torrente G., Sheu Ch.-J., Jessor's problem behavior theory: Cross-national evidence from Hungary, the Netherlands, Slovenia, Spain, Switzerland, Taiwan, Turkey, and the United States, „Developmental Psychology” 46(6)/2010, s. 1779-1791.

VAZsonyi A., TREJos-CASTILlo E., HUANG L., Youth violence across ethnic and national groups: Comparison of rates and developmental processes, w: D. FLANNERY, A. VAZSONYI, I. Waldman (ed.), The Cambridge Handbook of Violent Behavior and Aggression, New York 2007, s. 418-430.

WhitAKer D., MiLler K., Parent-adolescent discussions about sex and condoms: Impact on peer influences of sexual risk behavior, ,Journal of Adolescent Research” 15(2000), s. 251-273.

Whitbeck L., Yoder K., Hoyt D., CONGER R., Early adolescent sexual activity: A developmental study, „Journal of Marriage and the Family” 61(1999), s. 934-946.

White H., Loeber R., Stouthamer-Loeber M., FARrington D., Developmental Associations between Substance Use and Violence, „Development and Psychopathology” 11(1999), s. 785-803.

Williams J., Ayers C., Abbott R., Hawkins J., Catalano R., Racial differences in risk factors for delinquency and substance use among adolescents, „Social Work Research” 23(1999), s. 241-256.

Xue Y., Leventhal T., Brooks-Gunn J., Earls F.J., Neighborhood residence and mental health problems of 5- to 11-year olds, „Archieves of General psychiatry” 62 (5)/2005, s. $554-563$. 
ZAJDA K., Czym jest kapitał społeczny mieszkańców polskiej wsi, jak go mierzyć i czy warto inwestować w jego wzmocnienie?, „Acta Universitatis Lodziensis. Folia Sociologica” 37(2011), s. 171-185.

ZARYCKI T., Dwa wymiary kapitału społecznego w kontekście polskim, „Pomorski Przegląd Gospodarczy” 2 (37)/2008, s. 49-52.

ЖурАвЛЕВА Л.А., Учет в подготовке педагогов профессионального обучения виктимизации молодежи в городском пространстве, w: С.3. ГончАРовА (ред.), Креативность гуманитарного образования: духовно-ценностные и интеллектуальные аспекты, Екатеринбург: РГППУ 2014, s. 180-199.

ПоГОСов А.В., СтЕПАшов Н.С., ФИЛАТОвА Т.А., БУЛАТНИКовА О.М., Основные направления профилактики зависимости от психоактивных средств в подростковой среде, w: А.И. ЛАЗАРЕВ, В.А. ЛАЗАРЕНКО, О.О. КУРИЛОВА (ред.), Үниверситетская наука: теория, практика, инновации, Курск: ГОУ ВПО КГМУ Росздрава 2008, s. $298-303$.

SĄSIEDZKI KAPITAŁ SPOŁECZNY

A UŻYWANIE SUBSTANCJI PSYCHOAKTYWNYCH PRZEZ MŁODZIEŻ

S t r e s z c z e n i e

Celem artykułu jest opis związku pomiędzy sąsiedzkim kapitałem społecznym a zachowaniami problemowymi młodzieży, których jednym z przejawów jest używanie substancji psychoaktywnych. W części teoretycznej dokonano przeglądu literatury dotyczącej kapitału społecznego i jego rozumienia przez autorów prezentujących różne podejścia naukowe. Następnie opisano znaczenie relacji sąsiedzkich we współczesnym świecie. Dokonano również analizy epidemiologicznej spożywania przez młodzież substancji psychoaktywnych - alkoholu oraz narkotyków. Rozważania teoretyczne podsumowano prezentacją Teorii Zachowań Problemowych R. i S. Jessorów, która ujmuje relacje sąsiedzkie jako czynnik chroniący przed wystąpieniem zachowań ryzykownych u młodzieży. W części empirycznej artykułu zaprezentowane zostały wyniki badań przeprowadzonych na grupie młodzieży z terenu województwa lubelskiego. Oceniono w nich związek zachodzący pomiędzy posiadanymi relacjami sąsiedzkimi a używaniem legalnych oraz nielegalnych substancji psychoaktywnych.

Słowa kluczowe: kapitał społeczny; sąsiedztwo; używanie substancji psychoaktywnych; Teoria Zachowań Problemowych. 